Nuclear Instruments and Mothods 182-183(1981) p. $985-990$

- North-Holland Publishing Company

\title{
EFFELT OF ION IMPLANTATION ON THE OXYGEN OVERPOTENTIAL OF Ni ANODES
}

\author{
U. AKANO, J $\wedge$. DAVIES *, W.W. SMELTZER, IS. TASHLYKOV * and D.A. THOMPSON \\ Instirute for Materials Research, MCMaster University, Hamilton, Ontario, Canada L854M]
}

This work investigates the use of lon implantation for decrasing the oxygornoverpotential of nickel anoden It is part of a rearch for improved electrocalalysts to increzes the energy efinciency of the $\mathrm{H}_{2} \mathrm{O}$ electrolysis process for producins $\mathrm{H}_{1}$ man

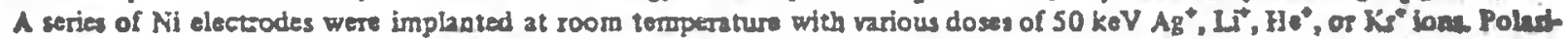

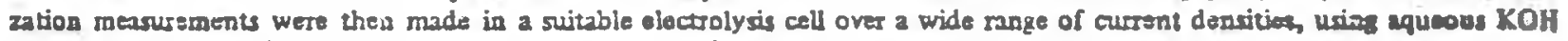

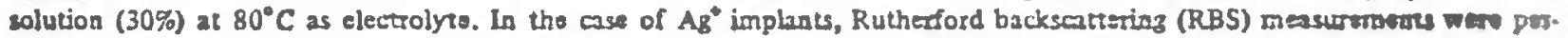
lormed before and after electrolysis in order to monitor the amount and depta distribution of the Ag atoms.

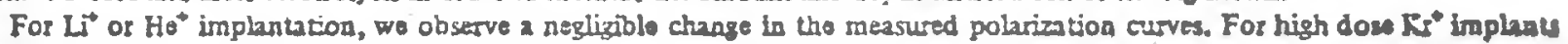
$\left(10^{18}\right.$ ions $\left.\mathrm{cm}^{-2}\right)$ the Ni electode exisbits an increass in overpolencial, indiating that excessive damage and/or spurterins of the surface causeas some detrioration is electrode behavious.

For Ag* implants, on the other hard, we observe a large $(20-409)$ zeduction in the cotal overpoisntial $2 t$ inglant doses of $0.3-4 \times 10^{16} \mathrm{Ag}^{+} \mathrm{cm}^{-2}$. Furthermore, RBS measurements show that prolonged electrolysis at highes current dacsity $(24-28 \mathrm{~h}$ at $1 \mathrm{~A} / \mathrm{cm}^{-2}$ ) produce only a small loss of $\mathrm{Ag}$ and shifts its depth profile to significantly larger depthe Supplementary puclear rucroanalysen, using the ${ }^{16} \mathrm{O}(\mathrm{d}, \mathrm{P})^{17} \mathrm{O}$ seaction, show that the shift in $\mathrm{Ag}$ profile is correlated with the growtis of an anodic nickel oxide (torsion) layer during electrolysis.

$\therefore$ In one set of runs, the Ni electrode, were thermally oxidized before $\mathrm{Ag}{ }^{*}$ implantation is order to fors an $-400 \mathrm{~A}$ layer of $\mathrm{NiO}$ at the surisce. Io this cise, wo observe a somewhat smaller reduction in overpotential following $A{ }^{*}$ ingliatation; furthermore, d harge loss of $\mathrm{Ag}$ in to the electrolyts ocaurs during the subsequen? electroly ris.

\section{Introduction}

Electrolysis of water is potentially a reversible process, but electrode polarization especially at the oxygen anode increases the required voltage sufficiently to prevent the technological divelopment of high efinciency electrolyse r and fuel cells. Most commercial electrolysers and fuel cells. Most commercial electrolysers consist of $\mathrm{Ni}$ electrodes immersed in a hot $25-50$ ut \% $\mathrm{KOH}$ electrolyte, but they operate at relatively low voltage efficiencies. Many other metals-for example, $\mathrm{Pt}, \mathrm{Ru}$ and $\mathrm{Ag}$-would offer superior electrocatalytic performance to $\mathrm{Ni}$, but these are generally too expensive for large scale commercial use. In this regard, ion implantation (or ion beaminduced mixing) 'several potential adyantages:

(i) the noble metal can be introduced into the near surface region (typically $<1000 \AA$ ) to a precise and controlled concentration;

- Atomic Energy of Canada limited, Chalk River, Ontario, Canada, KOJ 130.

* Visiting Scientist from Byeloruerian State Univeristy, Minsk, U.S.S.R. (ii) solid solubilities do not limit the maximum achievable concentration;

(iii) because only very near surface layers are being modified, the amount of noble metal can be mini. mized.

Several years ago, Grenness and Thompson [1] implanted Pt into tungsten and found that the elsc. trocatalytic activity of the surface approached that of platinum itself, even though only a rinute amount of platinum had been implanted. A similar study by Rabette et al., [2] examined the catalytic activity of single crystal supports of $\alpha-\mathrm{Al}_{2} \mathrm{O}_{3}$ and $\mathrm{MgO}$ implanted with platinum ions. Also, in a closely related series of studies, Deamaley [3] and others hava demonstrated the value of ion implastation in producing improved corrosion resistance for various metals.

In the present investigation, we have implanted selected species $\left(\mathrm{Li}^{\star}\right.$ and $\mathrm{Ag}$ ) into $\mathrm{Ni}$ and oxidized $\mathrm{Ni}$ anodes and have measured the resulting change in voltage efticiency as a function of electrolysis current in a suitable $\mathrm{H}_{2} \mathrm{O}$-electrolysis cell. In the case of the $\mathrm{Ag}^{+}$implants, Rutherford backsenitering (RBS) and nuclear microanalysis (NMA) have been used to monitor the Ag profile and the oxygen content of the 
anode before and after prolonged electrolysis. Even. tually, we hape to extend our inyestigation to include Pt implantation, but we do not yet have available the necessary ion source for producing $\mu \mathrm{A}$ beams of $\mathrm{Pt}^{*}$. Some high-dose inert gas $\left(\mathrm{He}^{\star}\right.$ and $\left.\mathrm{Kr}^{+}\right)$implants have also been studied in order to determine the possible contribution of radiation damage effects.

\section{Experimental}

Our 3-compartment electrolysis cell is shown in fig. 1. The main cell contains the hot ( $30 \mathrm{~m} \% \mathrm{KOH}$ ) electrolyte and the implanted $\mathrm{Ni}$ anods $\mathrm{A}$ (embedded in teflon) plus a $\mathrm{Pt}$ reference anode, Ayef; it is equipped with a cover to minimize evaporation loss.

The main variable electrolysis current flows between $A$ and the platinum cathode $C$ which is mounted in a separate compartment to minimize mix. Ing of electrolysis products. A much smaller constant current of $1 \mathrm{~mA}$ flows between a pair of Pt reference electrodes, $A_{\text {ref }}$ and $C_{\text {ref, }}$, with $C_{\text {ref }}$ also mounted in separate comparment with only a $2 \mathrm{~mm}$ connecting capillary to the main cell.

We measure th: potential $V_{1}$ between the nickel anode $A$ and the $P t$ reference cathode $C_{\text {ref. }}$. At the same time, we also measure the potential $V_{2}$ between $\mathrm{C}_{\text {Tef }}$ and a reversible $\mathrm{Pt}\left(\mathrm{H}_{2}\right)$ standard electrode, $\mathrm{R}$. This (dynamic cathode) potential is always quite small - l.e. $0.040 \mathrm{~V}$ - and hence the observed variations in $V_{1}$ are mainly due to overvoltage effects at or near the $\mathrm{Ni}$ anode. Note that $V_{2}$ will include some contribution from the (iR) voltage drop in the electrolyte near the amode. However, this is not a serious complication in the present work, since our

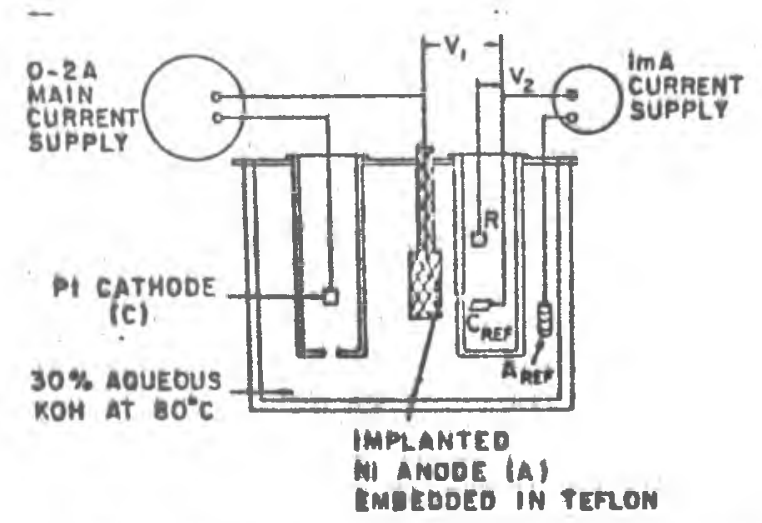

Fig. 1. Schematic diagnew of the 3-compartment dectrolysis coll.

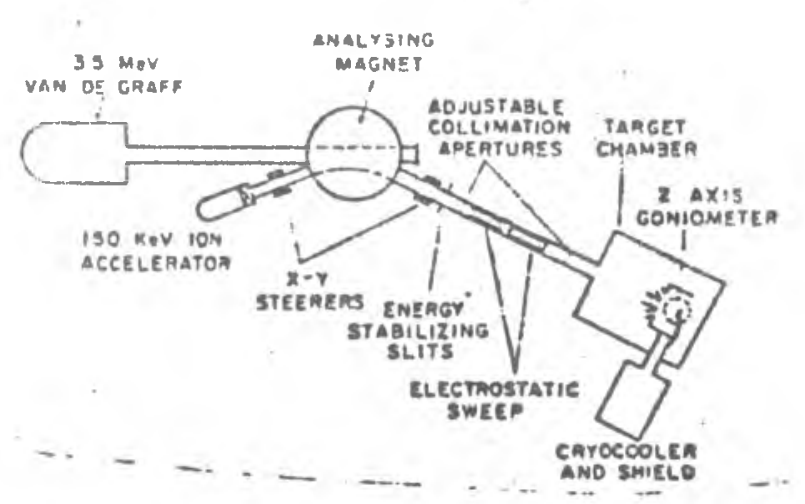

Fig. 2. Ion impleatation and RBS andy is faciliny.

initial objective is only to identify promising implan. tation systems which can then be investigated more rigorously.

The Ni anodes consisted of $9 \mathrm{~mm}$ diameter metal discs, mecharically polished with successively finer metallurgical paper and finally with $1 \mu \mathrm{m}$ diamond paste. After implantation, the anode was sealed into Its teflon holder with a sultable epoxy in order to define reproducibly the effective surface area during electrolysis.

Fig. 2 shows schematically the fon implantation facility at McMaster. The $150 \mathrm{kV}$ accelerator is usad for implanting the various lons, and the $3.5 \mathrm{MV}$ Van de Graaff is used for subsequent RBS analyses of the mount and depth profile of $\mathrm{Ag}^{+}$in the implanted electrode. Most of the $\mathrm{Ag}^{+}$implants and also the nucleap mictoanalyses were carried out at CRNL. All Implants were carried out at $300 \mathrm{~K}$ and $\sim 0.5 \mu \mathrm{A}$ $\mathrm{cm}^{-2}$. Note that a cryoshield at $\sim 30 \mathrm{~K}$ surrounds the target in order to maintain ultra-clean vacuum condl. tions during both the implantation and the RBS anal. ysis.

For the lightest ions $\left(\mathrm{He}^{*}\right.$ and $\left.\mathrm{U}^{*}\right)$, where the implant depth is quite large, each implant involved several different energies in order to obtain a rela. tively uniform depth distribution.

\section{Results and discusion}

\subsection{Overpotential measurements}

Iable 1 summarizes the obsorved effects of implantation on the oxygen overpotentra $n$ of the NI anode. Of the four implanted spectes studied to date. $A$ produced a imineant reduction in $\eta$, especially 
Table 1

Electochemical befiation of irrpianted Ni anodes

\begin{tabular}{|c|c|c|c|c|}
\hline $\begin{array}{l}\text { Implanied } \\
\text { apecies }\end{array}$ & Reasuri $t .2$ selection & $\begin{array}{l}\text { Implant } \\
\text { energy } \\
\text { (keV) }\end{array}$ & $\begin{array}{l}\text { Implane } \\
\text { dose } \\
\text { (ions } \mathrm{cm}^{-2} \text { ) }\end{array}$ & $\begin{array}{l}\text { Observed } \\
\text { afect on } n\end{array}$ \\
\hline $\mathbf{u}$ & $\begin{array}{l}\text { Li-Ni slluys give inproved oxide conductivity and } \\
\text { anode pealormancs }\end{array}$ & $15+40$ & $10^{15}-10^{16}$ & nil \\
\hline $\begin{array}{l}4 \mathrm{He}^{*} \\
\mathbf{K}\end{array}$ & $\begin{array}{l}\text { to invesurate the postible influmes of bombardment- } \\
\text { induced damage or sputtorins effects }\end{array}$ & $\begin{array}{l}15+40 \\
12\end{array}$ & $\begin{array}{l}10^{16}-10^{17} \\
-10^{16}\end{array}$ & nil $\operatorname{mill}$ incrime \\
\hline $\mathbf{A s}^{*}$ & $\begin{array}{l}\text { noble irutals (PT, Ru, etc) are known } 20 \text { be rench } \\
\text { better drucdes then } \mathrm{Ni}\end{array}$ & 50 & $\begin{array}{l}0.3-4.0 \\
\times 10^{16}\end{array}$ & $20-40 \%$ r thetion \\
\hline
\end{tabular}

at large values of the current density (i.e. $i \geq 0.1 \mathrm{~A}$, $\mathrm{cm}^{-2}$ )-2s seen in fig. 3. The other ions all had a aegligible effect on $\eta$, except $\mathrm{Ks}^{\star}$ which (at much higher dose) actually produced a snall increase in $\eta$.

Our observed curves of $\eta$ vs. current density for $\mathrm{Ag}^{*}$ implanted anodes appear to be independent of the implant dose (table 2) over the range 0.3-13X $10^{16} \mathrm{Ag}^{*} \mathrm{~cm}^{-2}$, but at tho highest dose used ( $4 X$ $10^{16} \mathrm{~cm}^{-2}$ ) a somewhat larger value of $\pi$ is obtained. Also, the $\mathrm{Ag}^{+}$-implanted $\mathrm{Ni}-\mathrm{NiO}$ anode how smaller improvement than $\mathrm{Ni}$ anode with the same $\mathrm{Ag}^{*}$ implant dose. As discussed later (fig.6), this dif-

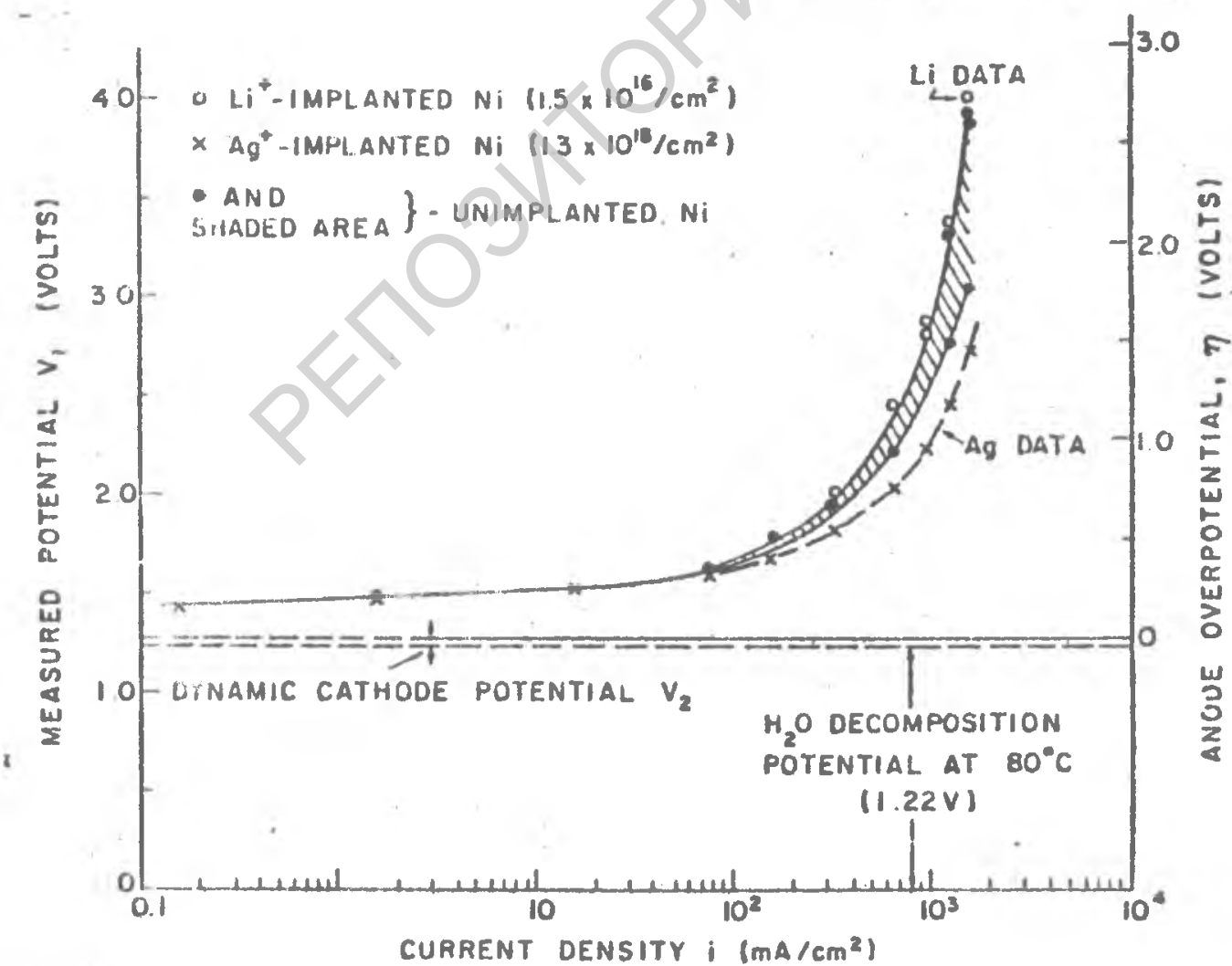

Fig. 3. Tafel plot of the observed potental $V_{1}$ vs. $\log /$ for $A_{8}^{*}(+), I^{+}(0)$ and unimplanted (shaded region) Ni anodos. The cor- . responding overpotential $(n)$ values are shown on the right hand scale. 
Table 2

Overpotential $n$ of $\mathrm{Ag}^{*}$ implanted Ni at $1 \mathrm{~A} \mathrm{~cm}^{-2}$

\begin{tabular}{lll}
\hline Target & $\begin{array}{l}\text { Implant } \\
\left(10^{1 / \mathrm{A}} \mathrm{Ag}^{-2} \mathrm{~cm}^{-2}\right)\end{array}$ & $\begin{array}{l}n \\
\mathrm{CV})\end{array}$ \\
\hline $\mathrm{NI}$ & 0.3 & 0.94 \\
& 0.6 & 0.99 \\
& 1.3 & 0.94 \\
& 4.0 & 1.14 \\
Nio & 1.3 & 124 \\
Unimplated & & $1.3-1.6$ \\
N! & & \\
\hline
\end{tabular}

ference is probably associated with the large loss of $\mathrm{Ag}$ during electrolysis in the pro-oxidized $\mathrm{Ni}-\mathrm{NiO}$ case.

One rather troublesome fenture of the unim. planted $\mathrm{Ni}$ anodes was a rather large variation in the observed overpotential from sample to sample-as shown by the shaded area in fig. 3. The $A_{g}+i m-$ planted anodes, on the other hand, gave mucb more reproducible $\eta$ vs. $\log t$ curves. A similar but less dramatic improvenent in reproducibility was also seen in the $\mathrm{L}^{*}$ and even in the $\mathrm{He}^{*}$ implants. Micto. scopic examination of these implanted anode surfaces after prolunged electrolysis show a much more uni. form corrosion film than on an unimplanted sample. Similarly, anodes which had been pre-oxidized to form an $-400 \AA$ surface NiO layer also exhibit much better reproducibility during electrolysis than the untreated $\mathrm{Ni}$ anodes-and a more uniform corrosion film.

The inert gas implants $\left(\mathrm{He}^{*}\right.$ and $\mathrm{Kr}$ ), at comparable doses to thoso used in the $\mathrm{Ag}^{\prime}$ study, show no detectable change in $\eta$-indicating that radiation damage effects are not playing a significant role in the observed $\eta$ reduction. Indeed, at considerably higher dose (i.e. $\sim 10^{18}$ ions $\mathrm{cm}^{-2}$ ), the $\mathrm{Ks}$-implanted anodes actually exhibit a small increase in $\eta$.

In the case of the $\mathrm{Lj}^{*}$ implants, the lack of a significant $\eta$ reduction (table 1 ) is sornewhat surprising, since it was already known [4] that the incorporation of $\sim 10 \% \mathrm{Li}_{2} \mathrm{O}$ into the oxidized surface of a $\mathrm{Ni}$ anode produces a marked increase in oxide conductivity and a consequent reduction in overpotential.

At $i$ values $50.1 \mathrm{~A} \mathrm{~cm}^{-2}$, our measured values of $V_{1}$ (and hence $\eta$ ) exhibit an approximately linear dependence on $\log i$, with the slope of this Tafel plot (fig. 3) being typically $\sim 0.05 \mathrm{~V}$. At higher $t$ values, however, $V_{1}$ increases much more rapidly and eventually approaches an almost linear dependence on $t$ (fig. 4) indicating that the (iR) drop in the elcctrolyte

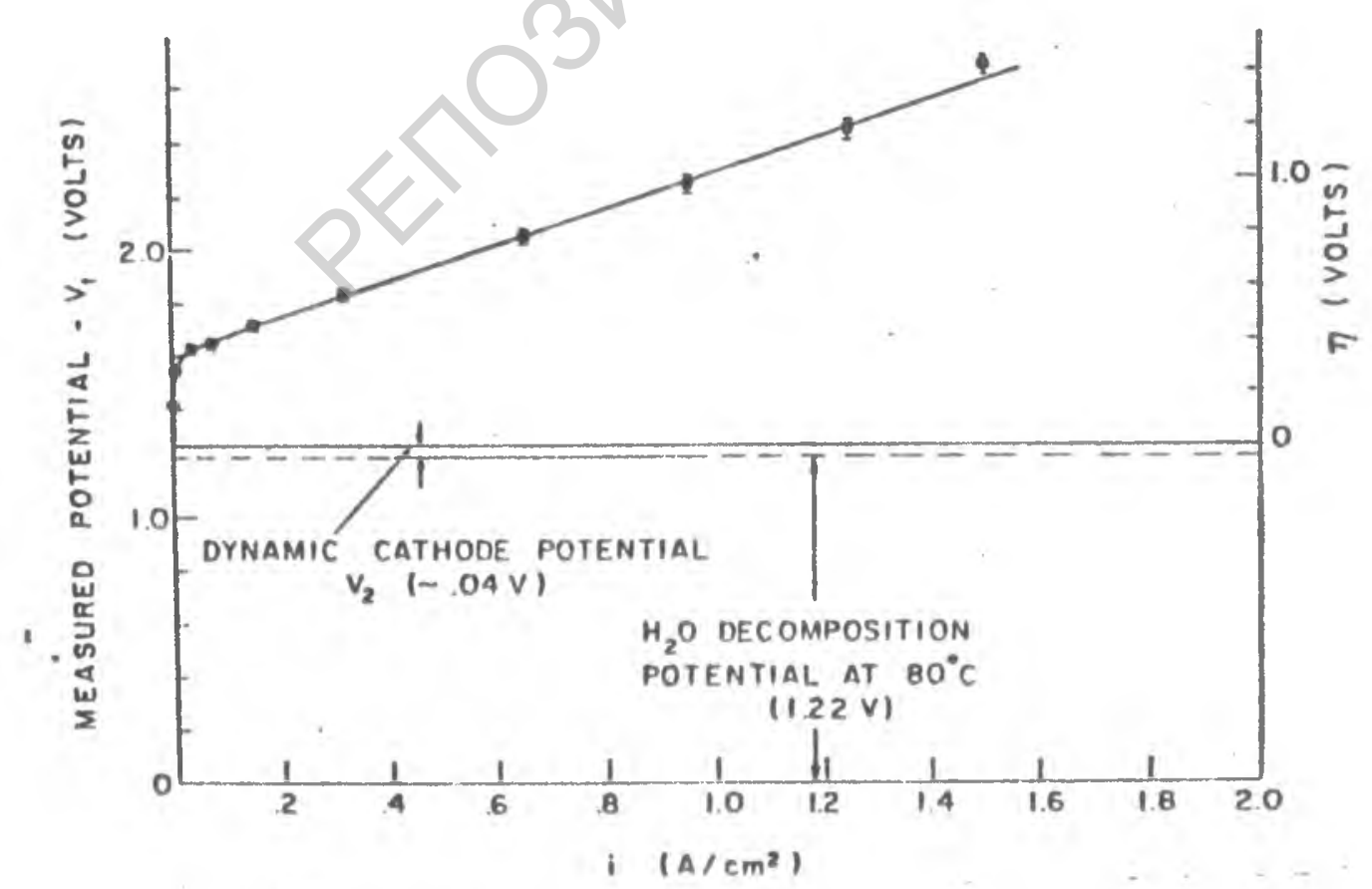

Fig. 4. Obstrved potential $V_{1}$ as a function of / for a $\mathrm{Ag}^{4}$-implanted $\mathrm{Ni}$ anode $\left(1.3 \times 10^{16} \mathrm{Ag}^{-2}\right.$ at $\left.50 \mathrm{keV}\right)$. 
near the anode is now starting to make a significant contribution to the $V_{2}$ measurements. Obviously, in future work, a more extensive potential-measuring technique will be required to disinguish the relative contribution of $\eta$ and (iR) drop to $V_{1}$.

\subsection{Anode discharge potential}

After each $\mathrm{Ni}$ anode had been subjected to a $24 \mathrm{~h}$ electrol: sis run, the current was turned off and the residual discharge potential was monitored for several hours. The $\mathrm{Ag}^{*}$-implanted anodes exhibit a welldefined plateau at $\sim 13 \mathrm{~V}$ (fig. 5) before dropping to the normal steady state value of $09 \mathrm{~V}$. It is interesting to note that the length of this plateau increases linearly with $\mathrm{Ag}^{*}$ implant dose and, from the known. impedance of the recording voltmeter $\left(1 \times 10^{6} \Omega\right)$, we estiruate that the integrated charge flowing during this plateau "phase" is equivalent roughly to two electrons per implunted Ag atom. This would suggest the formation, during electrolysis, of an intermediate complex involving the storage of rone oxygen ion per implanted Ag atom. Note that the unimplanted $\mathrm{Ni}$ anode exhibits no well-defined plateau at all.

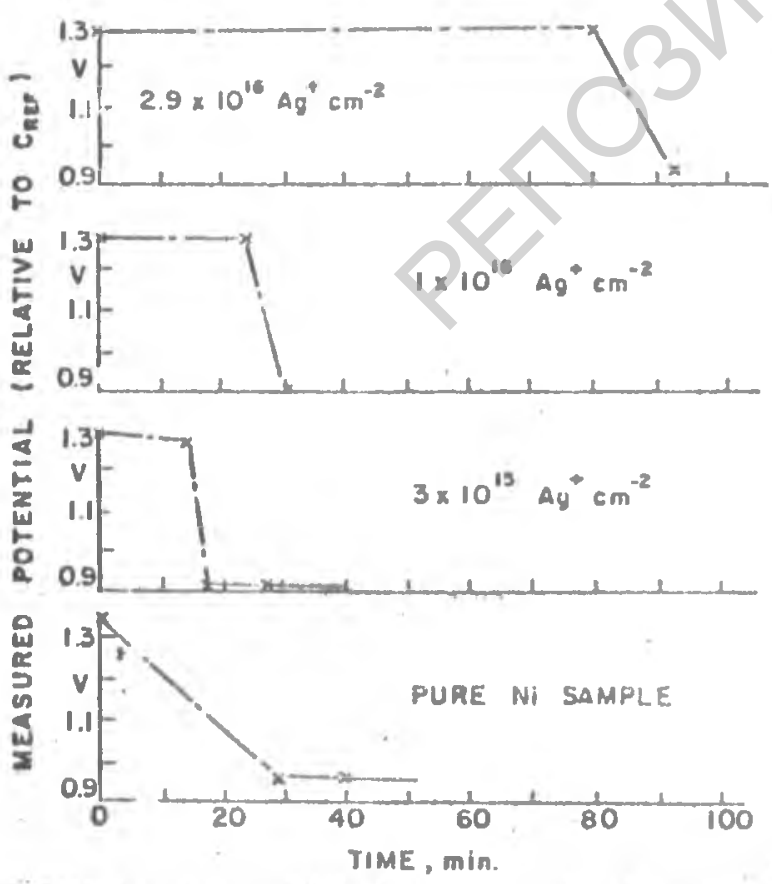

Fig. 5. Anode discharge potential $\left(V_{1}\right)$ with the electrolysis cursent turned off.

\subsection{Rutherford backscattering (RBS) and nuclear microanalysis (NMLA)}

Before and after electrolysis, each of the $\mathrm{Ag}$ implanted anodes was analysed by RBS, using a beam of $2.0 \mathrm{MeV}{ }^{4} \mathrm{He}^{*}$ ions. The resul's obtained on the $3 \times 10^{16}$ atoms $\mathrm{cm}^{-2}$ implant are shown in fig. 6 . The initial $\mathrm{Ag}$ peak position is seen to occur just slightly deeper than the predicted $R_{\text {LSS }}$ implant depth. After the first $24 \mathrm{~h}$ electrolysis run at $\sim 1 \mathrm{~A} \mathrm{~cm}^{-2}$, the $\mathrm{Ag}$ peak is shifted $200 \AA$ deeper into the $\mathrm{Ni}$, but its total area remains unchanged indieating that negligible loss of $\mathrm{Ag}$ has occurred.

Nuclear mictoanalysis, using $970 \mathrm{keV}$ deuterons and the ${ }^{16} \mathrm{O}(\mathrm{d}, \mathrm{p})^{17} \mathrm{O}$ reaction, shows that the $\mathrm{Ni}$ anode had picked up $\sim 2 \times 10^{17}$ oxygen atoms $\mathrm{cm}^{-2}$ during this first $24 \mathrm{~h}$ electrolysis; this is equivalent to the formation of $\sim 400 \AA$ of $\mathrm{NiO}$ on the anode sur. face. Trapping of $\mathrm{Ag}$ at this mobile $\mathrm{Ni}-\mathrm{NiO}$ interface could well explain the observed Ag peak shift in fig. 6. Simulaneous observation of the ${ }^{12} \mathrm{C}(\mathrm{d}, \mathrm{p})^{13} \mathrm{C}$ reaction yield shows that the surfacs "oxide layer" also contains a comparable number $\left(\sim 15 \times 10^{27}\right.$ $\mathrm{cm}^{-2}$ ) of carbon atoms and hence is more complex a molecular structure than $\mathrm{NiO}$.

Further electrolyses for additional $24 \mathrm{~h}$ periods

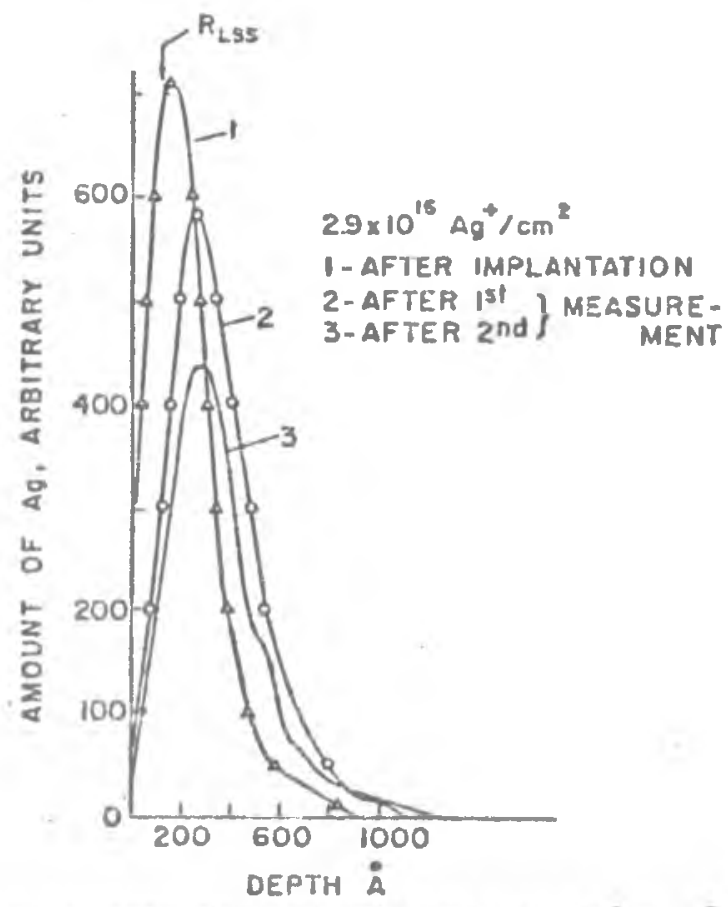

Fig. 6. KBS measurement of tho inglanted As profile in Ni before and after 24 h electrolysis runs. 
produce no further shift in the Ag peak position, but a gradual reduction in area occurs, indicating a gradual loss of $\mathrm{Ag}$ into the electrolyte.

A similar RBS study of $\mathrm{Ag}^{*}$ implanted into preoxidized $\mathrm{Ni}$ anodes ( $400 \mathrm{~A} \mathrm{NiO}$ ) shows no change in the Ag peak position but $>50 \%$ loss to the electrolyte during the first $24 \mathrm{~h}$ electrolysis period. The poorer electrolytic performance of the implanted $\mathrm{Ni}-\mathrm{NiO}$ anode (table 2) is probable related to this large loss of Ag into the electrolyte.

\section{Conchasions}

A very significant reduction in the anodic overpotential of nickel can be obtained by $\mathbf{A g}^{+}$implantation at $\sim 1 \times 10^{16}$ atoms $\mathrm{cm}^{-2}$, but more extensive electrochemical studies will be required to establish the relative contributions of oxygen overvoltage and electrolyte resistivity.
During electrolysis, the implanted Ag profule is swept several hundred $\mathrm{A}$ deeper into the $\mathrm{Ni}$, probably by trapping at the moving $\mathrm{Ni}-\mathrm{NiO}$ interface.

lnert gas $\left(\mathrm{He}^{*}, \mathrm{~K}^{*}\right)$ and $\mathrm{Li}^{*}$ implantations have negligible effect at $10^{13}-10^{16}$ atoms $\mathrm{cm}^{-2}$ implant doses.

We are especially grateful to Orville Westcott at CRNL for providing the Ag implantations.

\section{Referuoves}

[1] M. Gromess and MLW. Thompron, I. Appl Electrocherin 4 (1974) 211.

[2] P. Rabette, AM. Deano, A.J. Tench and M. Che, Chem Phyz Leth 60 (1979) 348.

[3] G. Dearnaloy and NE.W. Hartiog, Thin Solid Films 54 (1978) 215 ; aleo G. Deumaloy, this proceoding

[4] A.C.C. Tseung, B.S Hobbs and A.D.S. Tantran, Electron chem. Act 15 (1970) 473. 